\title{
Behaviorisme sebagai Pendekatan Tema dalam Rancangan Pusat Kreasi dan Eksplorasi Musik Indie di Surabaya
}

\author{
Ghanda Pradana Aprimianto ${ }^{1}$, Broto W. Sulistyo ${ }^{2}$, Ika Ratniarsih ${ }^{3}$ \\ 1,2,3Jurusan Arsitektur, Fakultas Teknik Sipil dan Perencanaan, Institut Teknologi Adhi Tama Surabaya \\ Email: ${ }^{1}$ ghandaprada@gmail.com
}

\begin{abstract}
.
The development of recent music is various and gets more creative. As a result, some effects come up such as the emergence and movement of Indie music including in Indonesia particularly in Surabaya as it has existed since 1990s. There have been so many Indie musicians who are reputable and even go-international. They have brought forward the name of Indonesia in the international stage. Unfortunately, this fact is contrary to the existing condition in which Indie music has not been accommodated well yet and gets less attention from music listeners and big record music labels. Indie music that should be free and independent and has strong idealism in creation has not been facilitated well yet. The site of Indie Music Exploration and Creation Centre is located on Mayjend Yono Suwoyo road, Pradahkalikendal, Dukuh Pakis, Surabaya City, East Java. It is near commercial areas of Pakuwon Trade Center (PTC) Surabaya, Lenmarc Mall Surabaya, and Intiland. The site borders consist of people's settlement at north and highway and Lenmarc Mall at south. Meanwhile, the west border involves parking area, unoccupied land, and people's settlement. The east border includes highway, house-shop, and Adhiwangsa apartment. Covering the area 5.3 hectares, the main facility comprises indoor music show building, amphitheater outdoor, and music training building, while the supporting facility involves music gallery, convention hall, café, and food court.
\end{abstract}

Keywords: free, independent, Indie music, appreciation

\begin{abstract}
Abstrak
Perkembangan musik dewasa ini sangat beragam dan semakin kreatif, salah satu dampak dari perkembangan musik tersebut adalah munculnya jalur dan pergerakan musik indie. Tidak terkecuali di Indonesia dan khususnya di kota Surabaya, yang sudah mulai mengenal jalur bermusik ini sejak tahun 1990an. Dan sudah banyak pula musisi-musisi indie yang berprestasi bahkan go international membawa nama baik Indonesia di kancah musik dunia. Hal tersebut berbanding terbalik dengan kondisi yang ada, dikarenakan jalur musik indie yang bebas dan mandiri serta memiliki idealisme yang kuat dalam berkarya, maka jalur musik ini kurang mendapat wadah serta perhatian dari para penikmat musik dan label rekaman besar. Letak lokasi site tepatnya berada di Jalan Mayjend Yono Suwoyo, Pradahkalikendal, Dukuh Pakis, Kota Surabaya, Jawa Timur. Site terletak dekat dengan area komersil yaitu Pakuwon Trade Center (PTC) Surabaya, Lenmarc Mall Surabaya dan Intiland. Batas utara site merupakan pemukiman warga, batas selatan site adalah jalan raya dan Lenmarc Mall. Sedangkan batas barat site adalah lahan parkir, tanah kosong dan pemukiman warga. Dan batas timur site adalah jalan raya, ruko dan apartemen Adhiwangsa. Dengan luas site sebesar 5,3 Ha, yang meliputi fasilitas utama seperti gedung pertunjukan musik indoor, amphiteater outdoor, dan gedung pelatihan musik. Sedangkan fasilitas pendukung seperti galeri musik, convention hall, cafe dan foodcourt.
\end{abstract}

Kata kunci : Bebas, Mandiri, Musik indie, Mengapresiasi

\section{Pendahuluan}

Semakin berkembangnya kesenian musik dewasa ini, berdampak pula pada munculnya pergerakan dan jalur musik yang berbeda-beda didunia. Salah satu yang mempunyai idealisme tinggi dalam bermusiknya adalah jalur musik indie.Tidak terkecuali di Indonesia yang sudah mulai mengenal pergerakan musik ini pada tahun 1990an sampai sekarang ini. Sudah banyak pula musisi-musisi serta penggiat musik indie yang bermunculan dan tersebar di berbagai kota, tidak terkecuali di kota Surabaya. Yang kualitasnya tidak kalah dari musisi non-indie, bahkan banyak yang lebih baik dalam segi 
musikalitas. Dan tidak sedikit pula yang sudah dikenal dan go internasional serta pastinya membawa nama bangsa di kancah musik dunia. Hal ini terbalik dari kenyataan .yang terjadi di dalam negerinya sendiri. Dikarenakan para musisi musik indie mempunyai idealisme yang kuat dalam bermusiknya, yang tidak mau masuk dalam major labels atau perusahaan rekaman besar, maka banyak dari mereka yang belum punya ruang serta fasilitas yang cukup untuk mengembangkan serta memproduksi maupun mendistribusikan karya musiknya. Hal itu disebabkan karena para musisi indie tidak ingin idealisme bermusiknya diatur dan dirusak oleh permintaan pasar dan industri musik yang hanya selalu mengutamakan keuntungan dan keinginan dari pasar musik yang mainstream. Akibatnya mereka masih belum terlalu dikenal luas di negerinya sendiri, tetapi malah lebih dikenal dan diapresiasi di negeri orang lain. Oleh karena itu perlu adanya fasilitas khusus yang mewadahi kegiatan bermusik para musisi indie tersebut berupa Pusat Kreasi Dan Eksplorasi Musik Indie Di Surabaya, sehingga masyarakat luas dapat mengenalnya lebih dalam serta memberikan apresiasi terhadap karya-karyanya. Dan bukan hanya itu, para musisi indie juga dapat memiliki ruang yang lebih untuk berkarya, memproduksi serta mendistribusikan karya-karyanya pada khalayak ramai. Serta menumbuhkan dan melahirkan musisimusisi baru yang terus meramaikan kancah musik di Surabaya pada khususnya dan di Indonesia bahkan dunia pada umumnya.Hal ini tentunya dapat menumbuhkan dapak yang positif pula khususnya bagi anak muda karena dapat mengarahkannya ke dalam kegiatan yang kreatif di bidang seni musik tanpa susah payah mencari fasilitas dan ruang bermusik.

\section{Tinjauan Pustaka}

\subsection{Arsitektur Berwawasan Perilaku}

Arsitektur Perilaku menurut Heimsath (1977) dalam bukunya dengan judul yang sama yaitu "Behavioral Architecture, towards an accountable design process", adalah perilaku dalam perancangan arsitektural, yaitu kaitan antara penghuni, bangunan dan hubungan diantara keduanya dalam konteks perilaku serta teknik perancangan arsitektur berbasis perilaku. Manusia sebagai makhluk sosial tidak pernah terlepas dari lingkungan yang membentuk diri mereka. Di antara sosial dan arsitektur dimana bangunan yang didesain oleh manusia, secara sadar atau tidak sadar, mempengaruhi pola perilaku manusia yang hidup di dalam arsitektur dan lingkungannya tersebut. Sebuah arsitektur dibangun untuk memenuhi kebutuhan manusia. Begitu pula sebaliknya, dari arsitektur itu lah muncul kebutuhan manusia yang baru kembali.

\subsection{Kajian Behaviorisme dalam Arsitektur}

Hal yang sedana dinyatakan oleh Tandal \& Egam (2011), bahwa arsitektur membentuk perilaku manusia, manusia membangun bangunan demi pemenuhan kebutuhan pengguna, yang kemudian bangunan itu membentuk perilaku pengguna yang hidup dalam bangunan tersebut. Bangunan yang didesain oleh manusia yang pada awalnya dibangun untuk pemenuhan kebutuhan manusia tersebut mempengaruhi cara kita dalam menjalani kehidupan sosial dan nilai-nilai yang ada dalam hidup. Hal ini menyangkut kestabilan antara arsitektur dan sosial dimana keduanya hidup berdampingan dalam keselarasan lingkungan. Untuk membentuk perilaku manusia dapat dipengaruhi oleh beberapa perancangan fisik ruang, seperti ukuran dengan bentuk ruang, perabot dan penataannya, warna, suara, temperatur, dan pencahayaan.

Perilaku manusia membentuk arsitektur Manusia membangun bangunan, yang kemudian membentuk perilaku manusia itu sendiri. Setelah perilaku manusia terbentuk akibat arsitektur yang telah dibuat, manusia kembali membentuk arsitektur yang telah dibangun sebelumnya atas dasar perilaku yang telah terbentuk, dan seterusnya.

Perilaku manusia dalam hubungannya terhadap suatu setting fisik berlangsung dan konsisten sesuai waktu dan situasi. Karenanya pola perilaku yang khas untuk setting fisik tersebut dapat diidentifikasikan. Tentu saja apa yang dibahas tidak lantas menjadi demikian sederhana bahwa manusia semuanya berperilaku dalam suatu tempat dan waktu tertentu. Tapi umumnya frekuensi kegiatan yang terjadi pada suatu setting baik tunggal ataupun berkelompok dengan setting lain menunjukkan suatu yang konstan/tetap sepanjang waktu. Ini menunjukkan bahwa tidak hanya karakter dan pola tetap perilaku yang dapat dideteksi dalam hubungannya dengan suatu setting tapi juga kemungkinan yang muncul seperti pola tanggapan perilaku yang kadang dapat berubah menjadi sebaliknya. Hal - hal yang 
perlu kita ketahui juga adalah perancangan fisik ruang yang mempunyai variable - variable yang berpengaruh terhadap perilaku penggunaanya yaitu:

(a) Ukuran dengan bentuk ruang, ukuran dan bentuk ruang yang tidak tepat akan mempengaruhi psikologis dan tingkah laku penggunanya. Penerapan: ukuran ruang disesuaikan dengan kebutuhan pengguna, dimana ukuran ruangan tersebut disesuaikan dengan aktivitas dan kebutuhan pengguna dalam suatu ruangan tersebut. Bentuk ruang lobi, tempat ibadah, ruang rehabilitasi, auditorium mengambil bentuk - bentuk lengkung untuk memberi kesan dinamis, riang, dan memberi pengaruh gembira;

(b) Perabot dan penataannya, perabot di buat untuk memenuhi tujuan fungsional dan penataannya mempengaruhi perilaku penggunanya. Penerapan: penataan perabot dalam ruang disesuaikan dengan kebutuhan serta aktivitas pengguna ruang;

(c) Warna, memiliki peranan penting dalam penciptaan suasana ruang dan mendukung perilaku perilaku tertentu. Warna berpengaruh terhadap tanggapan psikologis dan berpengaruh terhadap kualitas ruang. Penerapan: warna yang digunakan dalam ruangan harus memiliki nilai positif yang dapat merubah atau mempengaruhi perilaku negative;

dan (d) Suara, temperature dan pencahayaan, unsur - unsur ini mempunyai andil dalam mempengaruhi kondisi ruang dan penggunanya. Suara yang keras dapat menggangu ketenangan seseorang. Penerapan: agar tidak menggangu ketenangan dengan suara keras, maka ruang dibuat kedap suara agar suara tidak menggangu ketenangan ruangan lain. Tempertatur berpengaruh dengan kenyamanan pengguna ruang, dimana suhu ruang sangat mempengaruhi kenyamanan ruang (thermal confor untuk orang Indonesia ialah antara $25,4^{\circ} \mathrm{C}-28,9^{\circ} \mathrm{C}$ ). Pencahayaan dapat mempengaruhi kondisi psikologis seseorang. Ruang yang cenderung minim pencahayaannya membuat orang menjadi malas dan jika terlalu terang dapat menyebabkan silau dan menyakitkan mata.

\subsection{Musik Indie}

Menurut Naldo (2012), secara harfiah, indie merupakan kependekan dari independent. Indie berarti merdeka, sendiri, yang berdiri sendiri, yang berjiwa bebas. Secara istilah, indie mempunyai definisi menjadi tidak tergantung pada aliran yang umum atau popular saat ini (mainstream). Tidak hanya sekedar mandiri, namun menjadi indie berarti harus berani tampil beda dan berani melakukan percobaan. Kata indie ini pun sering dihubungkan dengan musik, film, media cetak, dan bisnis independen. Senada dengan prinsip independent, Anggoro (2010) menggunakan kata indie, suatu kreasi artistik akan dianggap berada diluar aliran komersial, yaitu tanpa dukungan dari major label, studio mayor, atau sumber lain dengan keuangan yang melimpah.

Memang cukup membingungkan kalau definisi tersebut disajikan kepada masyarakat awam. Namun dalam bahasa yang sederhana, musik indie didefinisikan sebagai musik yang bukan mainstream (musik yang populer). Tema lagu dan aliran musiknya bebas, terserah sang musisi. Pada kesimpulannya, indie merujuk pada usaha secara mandiri dan bebas dalam berkarya, memproduksi, dan merencanakan pola distribusi yang bersifat self-released dan limited.

\section{Metode Penelitian}

Jenis penelitian yang digunakan adalah penelitian deskriptif, penelitian ini berkaitan dengan pengumpulan data untuk memberikan gambaran tentang suatu gejala, umumnya dilakukan dengan metode survey, wawancara, pengamatan, studi kasus, studi korelasi, dsb. Dengan pengumpulan data untuk memberikan gambaran tentang suatu gejala.

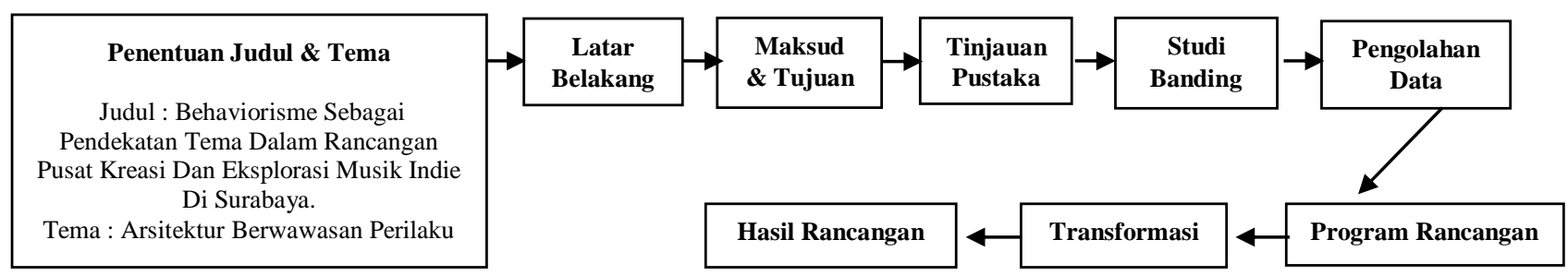

Gambar 1. Diagram Metode Penelitian 


\section{Studi Banding Obyek Kasus} berikut:

Hasil dari studi banding lapangan dan literatur yang berkaitan dengan tema desain sebagai

\subsection{Studi Banding Lapangan}
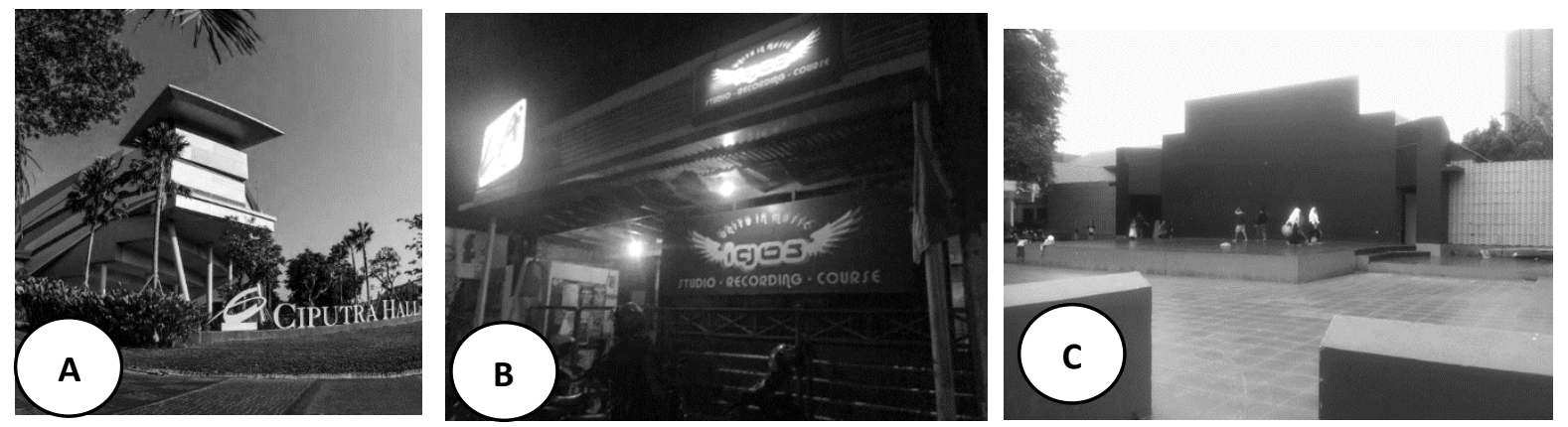

Gambar 2. Tampak Perspektif Ciputra Hall (A), Tampak Depan Igos Music Studio (B), Tampak Perspektif Panggung Terbuka Cak Durasim (C)

Sumber: Dokumentasi Pribadi 21/07/2017

Pada gambar A, yaitu objek studi banding lapangan Ciputra Hall, dapat disimpulkan bahwasanya dari segi desain bentuk bangunannya sudah memenuhi konsepnya yang modern dan berkelas tinggi. Desain bangunan maupun interiornya sudah disesuaikan dengan perilaku dan aktivitas pengguna didalamnya. Dalam hal ini kesan yang diberikan pada bentuk eksterior bangunan, maupun kesan desain interior didalamnya sebagai tempat pertunjukan seni yang mengutamakan kebebasan, dinamis dan kenyamanan dalam penerapannya. Elemen akustik pada ruang auditorium sudah sangat diperhitungkan, sehingga akustiknya sangat baik. Dengan menyalurkan dan memantulkan bunyi secara merata dari depan panggung hingga belakang tempat duduk penonton.

Pada gambar B, yaitu objek studi banding lapangan Igos Music Studio, dapat disimpulkan bahwasanya dari segi arsitektural dan interior bangunannya memang terkesan sederhana, tetapi sudah menyajikan nuansa yang autentik dan eksklusif pada desainnya. Sehingga memberikan pengalaman tersendiri saat berada di sana. Telah cukup memenuhi kebutuhan pengunjungnya yang mana para musisi indie yang membutuhkan tempat untuk berlatih, bersosialisasi dan mengembangkan minat bakatnya.

Pada gambar C, yaitu objek studi banding lapangan Panggung Terbuka Cak Durasim, dapat disimpulkan bahwa dari segi fungsi bangunannya sendiri sudah memenuhi segala aktivitas yang ada didalamnya, yaitu sebagai gedung pertunjukan terbuka sekaligus sebagai tempat latihan pertunjukan. Dari segi arsitektural bangunannya sendiri juga sudah memenuhi kriteria desain yang ada. Dengan bentuk yang simetris ditambah dengan permainan bentuk bidangnya.

\subsection{Studi Banding Literatur}
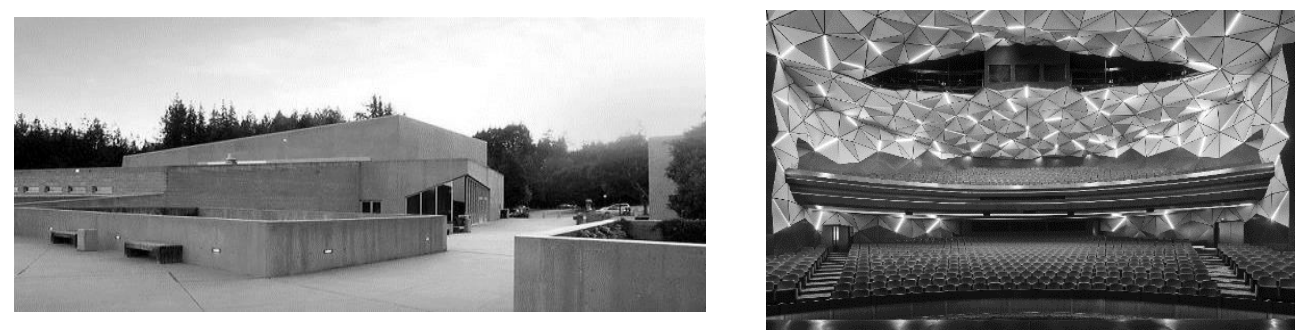

\section{Gambar 3. Tampak Perspektif UC Santa Cruz Music Center (kiri), Tampak Perspektif Indoor Ciputra Artpreneur (kanan) \\ Sumber: ucsc.edu (kiri), archdaily.com (kanan)}

Pada gambar sebelah kanan, yaitu objek studi banding literatur UC Santa Cruz Music Center, dapat disimpulkan bahwa dari segi arsitektural bangunannya sendiri sudah tanggap terhadap 
lingkungan disekitarnya, baik lingkungan alamnya maupun lingkungan sosial penggunanya. Sudah sangat memenuhi fungsi dari bangunannya sendiri yang merupakan bangunan pertunjukan, pelatihan dan pengembangan serta pendidikan musik. Dari segi akustik serta elemen penunjang interiornya sudah diperhitungkan secara matang sehingga dapat menunjang kegiatan bermusik didalamnya.

Pada gambar sebelah kiri, yaitu objek studi banding literatur Ciputra Artpreneur, dapat disimpulkan bahwa sudah memenuhi fungsinya sebagai pusat seni yang modern dan mewah, dengan material dan desain interior yang eksklusif dan memanjakan para pengguna di dalamnya. Memiliki kapasitas serta pola ruang yang dapat mengakomodir kegiatan seni didalamnya secara fleksibel. Telah memenuhi proporsi, keseimbangan, harmoni serta kesatuan didalam desainnya baik eksterior maupun interiornya.

\section{Lokasi dan Fasilitas Rancangan}

Lokasi site tepatnya berada di Jalan Mayjend Yono Suwoyo, Pradahkalikendal, Dukuh Pakis, Kota Surabaya, Jawa Timur. Site terletak dekat dengan area komersil yaitu Pakuwon Trade Center (PTC) Surabaya, Lenmarc Mall Surabaya dan Intiland. Batas utara site merupakan pemukiman warga, batas selatan site adalah jalan raya dan Lenmarc Mall. Sedangkan batas barat site adalah lahan parkir, tanah kosong dan pemukiman warga. Dan batas timur site adalah jalan raya, ruko dan apartemen Adhiwangsa. Dengan luas site sebesar 5,3 Ha, yang meliputi fasilitas utama seperti gedung pertunjukan musik indoor, amphiteater outdoor, dan gedung pelatihan musik. Sedangkan fasilitas pendukung seperti galeri musik, convention hall, cafe dan foodcourt.

\section{Program Rancangan}

Program rancangan adalah pengumpulan, pengorganisasian, analisis, peng-interpretasi-an, dan pemaparan dari informasi yang relevan untuk proyek yang didesain. Program rancangan juga merupakan suatu pendekatan rancangan dari permasalahan-permasalahan yang ada untuk mencapai tujuan yang diinginkan dan menghasilkan suatu rancangan yang lebih terarah.

\subsection{Program Rancangan pada Bentuk}

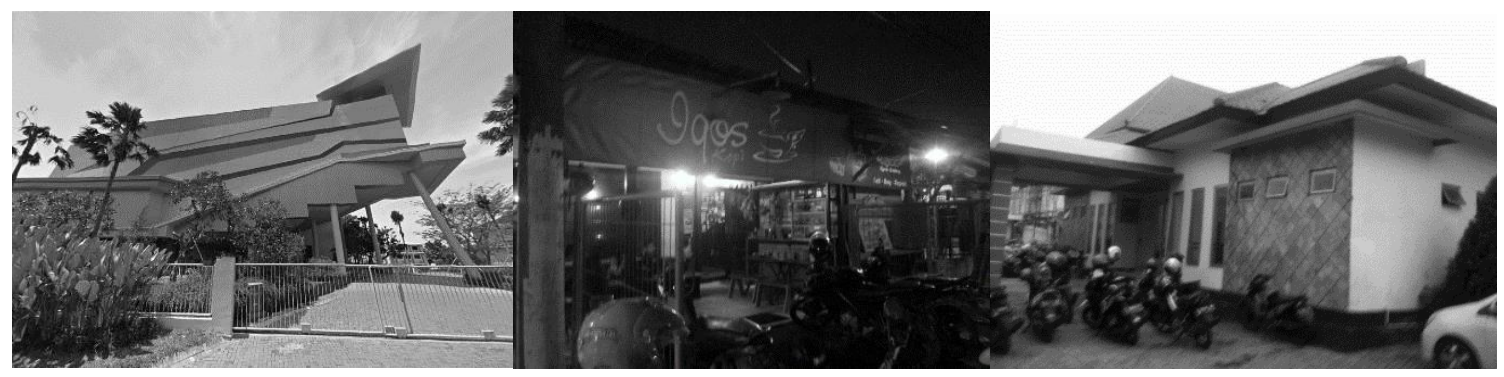

Gambar 4. (kiri) Tampak Samping Ciputra Hall; (tengah) Tampak Perspektif Igos Music Studio; dan (kanan) Tampak Perspektif Belakang Panggung terbuka Cak Durasim Sumber: Dokumentasi Pribadi 21/07/2017

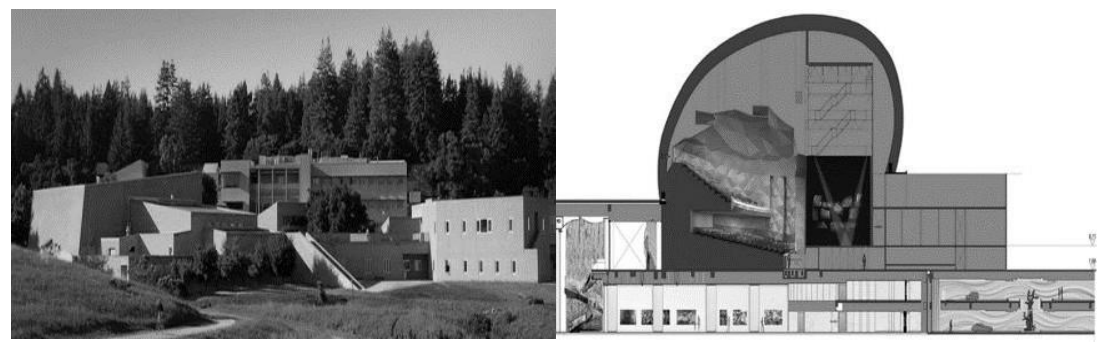

Gambar 5. (kiri) Perspektif UC Santa Cruz; dan (kanan) Potongan bangunan Ciputra Artpreneur Sumber: (kiri) ucsc.edu; dan (kanan) Archdaily.com

Fakta: Pada Ciputra hall menggunakan bentukan yang asimetris, dimana didasarkan pada bentuk trapezium. Terdapat variasi detail bentuk maju-mundur serta kemiringan garis-garis horizontal. 
Yang memberi kesan elegan, dinamis dan modern. Pada Igos Music Studio memiliki tampilan desain bangunan yang sederhana, dengan bentuk simetris persegi panjang pada keseluruhan desainnya. Pengolahan bentuk yang sederhana tersebut memberikan kesan yang simple dan minimalis. Pada Panggung Terbuka Cak Durasim menggunakan bentukan yang simetris pada tampilan luar bangunan. Terdapat permainan bidang untuk memecah kekakuan antar bentukan bidang simetrisnya. Yang memberi kesan formal dan kokoh. Pada bangunan UC Santa Cruz Music Center memiliki tampilan bentuk desain bangunan yang simetris sekaligus asimetris. Dengan bentukan dasar persegi dan persegi panjang. Dengan menggunakan permainan kemiringan bidangnya yang beradaptasi dengan bentuk topografi lingkungan sekitarnya yang berbukit. Dan pada Ciputra Artpreneur memiliki tampilan desain yang modern, megah dan berkelas. Penggunaan material yang memadukan unsur tradisional dan modern membuat perpaduan yang unik pada tampilannya.

Isu: Bagaimana merancang sebuah fasilitas musik yang dapat menampilkan serta mengakomodir kegiatan beraktivitas para penggiat musik indie di dalamnya.

Goal: Menghasilkan rancangan yang sesuai dan dapat mengakomodir segala kegiatan bermusik indie, sehingga terjadi hubungan antara pengguna (penggiat musik indie) dan bangunan.

Performance requirements: Bentuk bangunan yang lebih dinamis dan autentik dengan permainan bidang-bidangnya baik simetris ataupun asimetris, sehingga memberi kesan yang original dan meniliki daya tarik desain tersendiri. Memperpadukan warna serta material bangunan yang menunjang bentuknya, sehingga terkesan tidak terlalu kaku. Penggunaan material bangunan yang tanggap terhadap aktivitas atau kegiatan bermusik, agar tidak menyusahkan pengguna dalam melakukan aktivitasnnya.

Partial Idea:
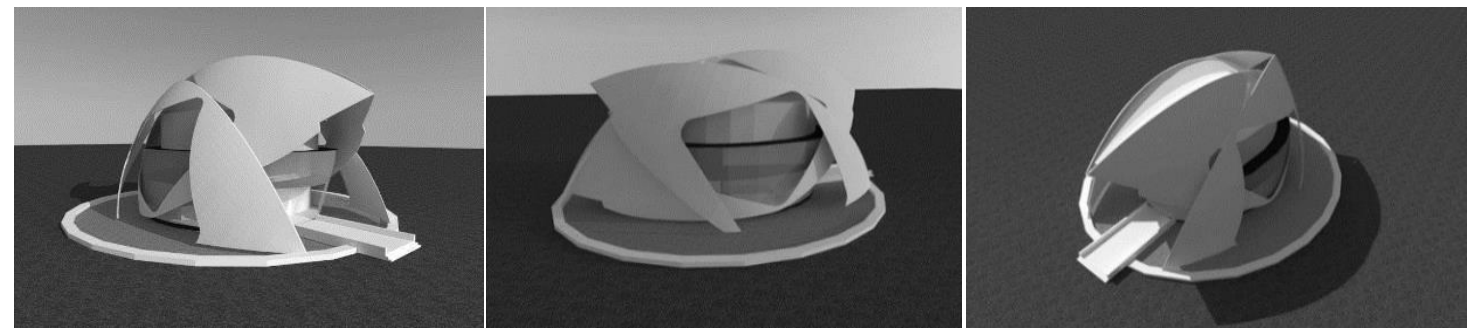

Gambar 6. (kiri) Tampak Perspektif bentuk Partial Idea; (tengah) Tampak Samping bentuk Partial Idea; dan (kanan) Tampak Perspektif Atas bentuk Partial Idea

\subsection{Program Rancangan Pada Ruang}
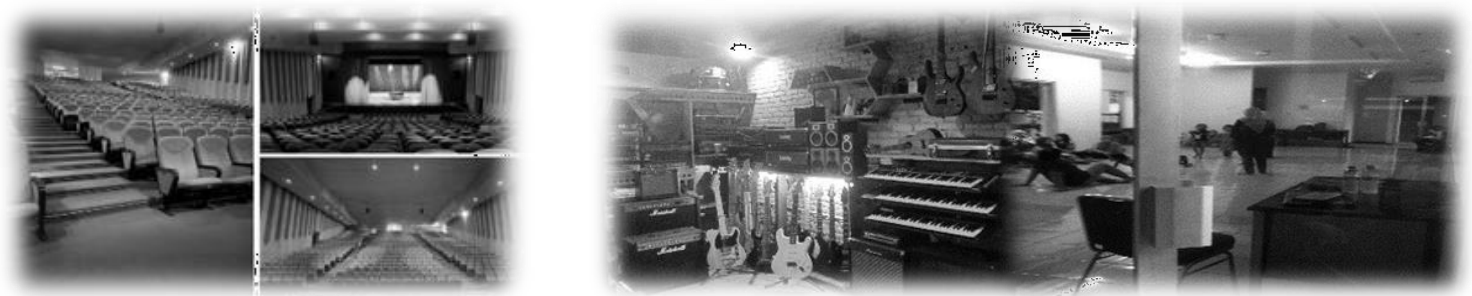

Gambar 7. (kiri) Tampak Indoor Ciputra Hall; (tengah) Tampak Interior Igos; dan (kanan) Tampak Interior Panggung Terbuka Cak Durasim
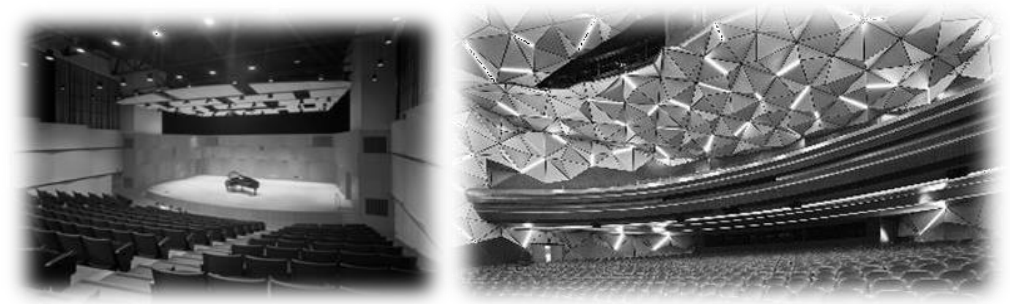

Gambar 8. (kiri) Tampak Interior UC Santa Cruz Music Center; dan (kanan) Tampak Indoor Ciputra Artpreneur 
Fakta: Pada ruang Ciputra Hall adalah Pada dinding sudah di lapisi dengan lapisan fabric covered absorber, dan pada lantainya juga digunakan karpet fabric untuk menyerap suara agar tidak keluar ruangan dan menjaga pantulan suara di dalam auditorium tersebut. Pada Igos Music Studio tatanan elemen interior pada objek tersebut disusun dengan mengikuti bentuk ruangan, agar dapat serasi dengan ruangannya. Dengan menggunakan perabot untuk sound system dan alat-alat musik. Pada ruang panggung terbuka cak durasim backstagenya terdapat sirkulasi untuk masuk dan keluar panggung yang ada di pojok kanan \& kiri ruangannya. Dari bentuk denahnya, cukup sederhana, dimana berbentuk persegi panjang, dan hanya terdapat ruang service di kanan-kirinya. Pada UCSC Music Center desain akustik pada hall dapat dilihat dari 6 tirai kanopi di atas panggung untuk menyembunyikan ruang gema dan waktu dengung di aula menjadi dua kali lipat. Terdapat jalur sirkulasi disepanjang sekitar panggung serta loading dock yang memungkinkan kegiatan bongkar muat ke panggung. Dan pada ruang indoor Ciputra Artpreneur memadukan material serta warna yang berkesan hangat dan dingin untuk interiornya. Seperti kayu dan logam, serta warna soft dan warna gelap. Menggunakan aksentualitas berupa garis-garis, baik lengkung dan lurus secara tegas dan dinamis, yang membentuk sebuah bidangbidang dengan diterangi pencahayaan.

Isu: Bagaimana menciptakan ruang yang dapat memenuhi dasn mengakomodir serta memperhatikan aspek akustik sebagai wadah beraktivitas para penggiat musik indie.

Goal: Menghasilkan rancangan ruang yang sesuai dengan aktivitas penggiat musik indie, dimana memperhatikan sirkulasi ruang yang efektif dan se-efisien mungkin. Serta memperhatikan aspek akustik ruang sehingga dapat mewadahi proses bermusik didalamnya.

Performances requirements: Sirkulasi di dalam bangunan yang paling tepat diusahakan secara efektif dan efisien, agar tidak membingungkan pengguna dalam beraktivitas. Penggunaan desain akustik ruangan disesuaikan dengan jenis kegiatan bermusik didalamnya. Di antaranya menggunakan material fabric untuk menyerap bunyi dan tirai/ panel kanopi untuk memantulkan suara agar tersebar merata ke seluruh ruangan. Penggunaan elemen interior yang sesuai dengan fungsi sekaligus penambahan aksentualitas untuk membangkitkan kreativitas bermusik para penggunanya. Penggunaan pencahayaan dan penghawaan buatan untuk ruangan yang tertutup dengan menggunakan AC dan kipas angin sesuai dengan aktivitas didalamnya. Sedangkan untuk pencahayaan dan penghawaan alami untuk ruangan yang tidak tertutup dengan membuat bukaan-bukaan sebagai masuknya sinar matahari.

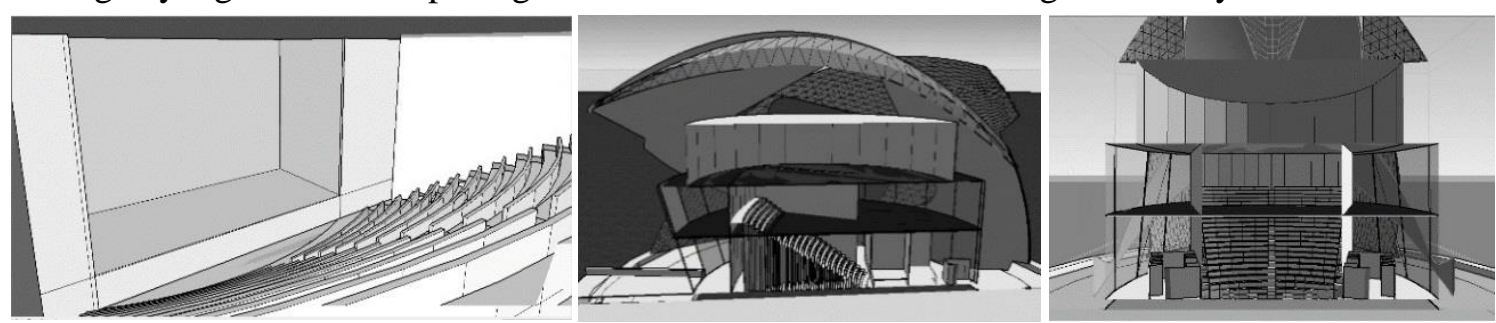

Gambar 9. (kiri) Tampak Interior ruang hall partial idea; (tengah) Potongan melintang bangunan hall partial idea; dan (kanan) Potongan membujur bangunan hall partial idea

\subsection{Program Rancangan pada tatanan lahan}
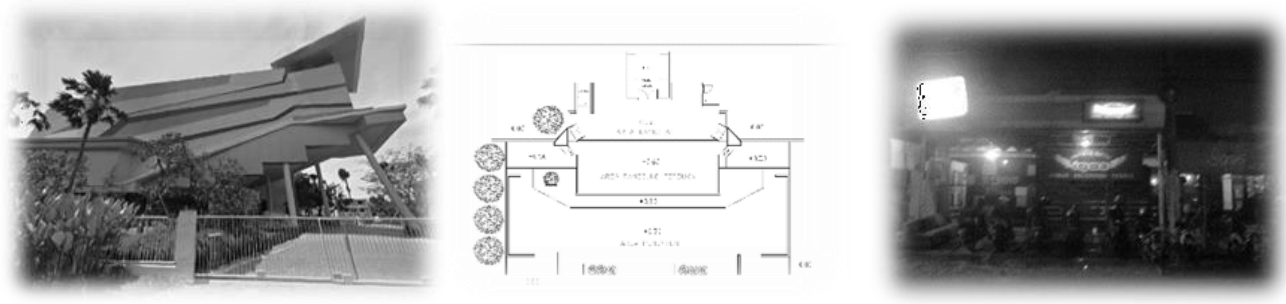

Gambar 10. (kiri) Lansekap Ciputra Hall; (tengah) Denah Panggung Terbuka Cak Durasim; dan (kanan) Tampak Depan Igos Music Studio 


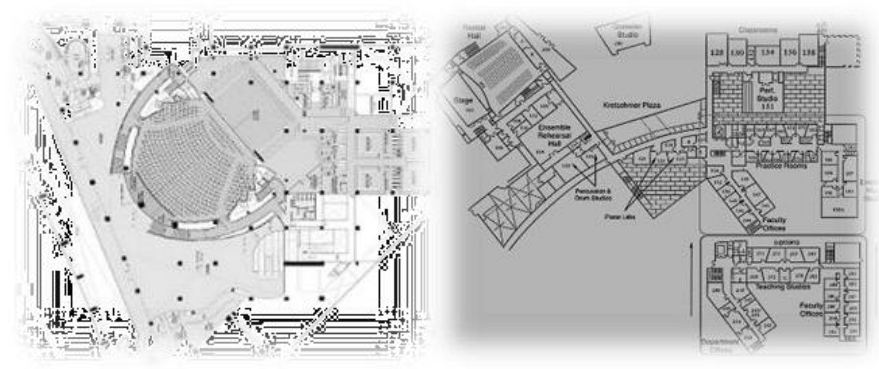

\section{Gambar 11. (kiri) Denah Ciputra Enterpreneur; dan (kanan) Denah UCSC Music Center}

Fakta: Pada lansekap ciputra hall Objek tersebut berada di tengah-tengah lahannya, sebagai pusat aktivitas pada site tersebut. Dibagian samping \& depan bangunan terdapat sirkulasi jalur kendaraan yang akan masuk, serta dropping area. Sedangkan untuk parkir berada di belakang bangunan. Pada panggung terbuka Cak Durasim tatanan massa pada objek tersebut mengikuti lahan/ tapaknya yang persegi panjang. Bagian utama panggung dan backstagenya berada di bagian belakang, sedangkan area penonton berada di depan. Pada Igos Music Studio diarea depan pintu masuk terdapat parkiran untuk kendaraan. Yang dijajar sepanjang bangunannya. Sedangkan main entrance berada di bagian kiri bangunan. Pada gedung Ciputra Artpreneur lahannya mempunyai aksesbilitas yang sangat baik. Penataan lahannya tanggap dengan massa bangunannya sendiri. Dan pada bangunan UCSC Music Center tatanan massa pada objek tersebut didesain untuk beradaptasi dengan lingkungan sekitarnya yang berbukit-bukit. Bentuk tatanan massanya asimetris dan memanjang mengikuti tapaknya yang berbukit.

Isu: Bagaimana merancang sirkulasi dan menata massa bangunan didalam site dengan memperhatikan perilaku pengguna (penggiat musik indie) yang beraktivitas didalamnya, sehingga dapat memudahkan serta mengakomodir segala jenis aktivitas. Serta menata vegetasi, hardscape dan softscape untuk menunjang desain lansekap didalam site.

Goal: Menghasilkan hasil rancangan tatanan lahan yang mengacu pada aktivitas bermusik indie serta memperhatikan penggunaan vegetasi dan elemen lansekap lainnya yang sesuai dengan perilaku pengguna.

Performances requirements: Tatanan massa ditata dengan memperhatikan aktivitas pengguna dan fungsinya. Sirkulasi pejalan kaki dan kendaraan harus dibedakan secara jelas. Penambahan vegetasi berupa tanaman hias, tanaman peneduh dan tanaman pengarah. Penataan massa menggunakan pola sirkulasi kurva linear dan network.

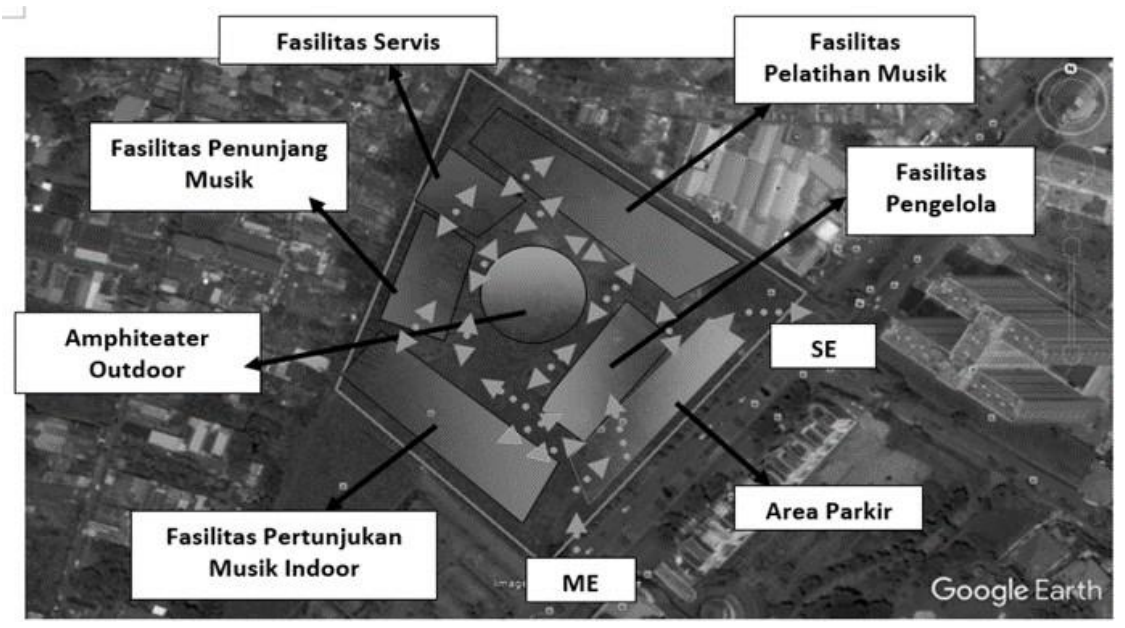

Gambar 12. Partial Idea penataan massa bangunan dan sirkulasi site. Sumber: dokumen pribadi 25/08/18

\section{Transformasi dan Hasil Rancangan}




\subsection{Tatanan Lahan}

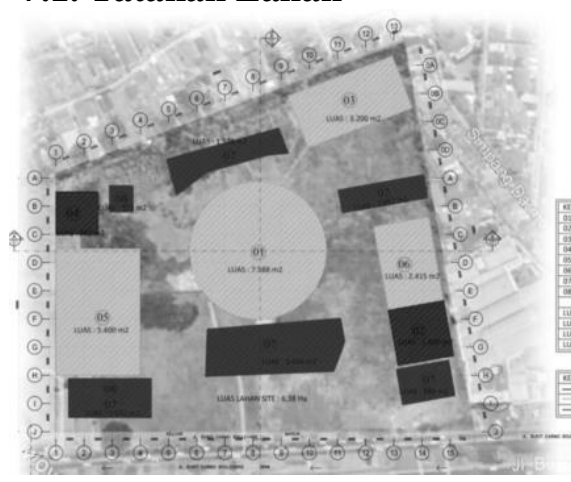

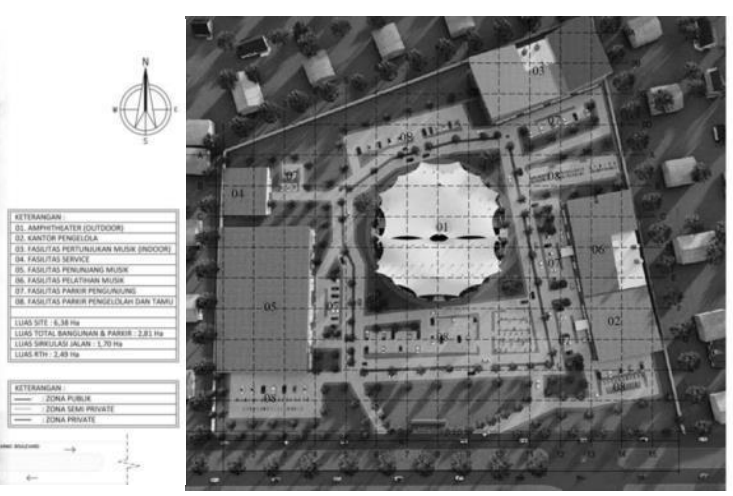

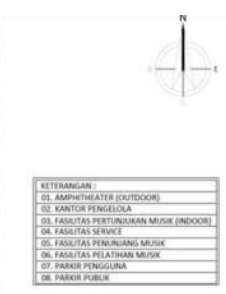

Gambar 13. (kiri) Blokplan site; dan (kanan) Siteplan Sumber : dokumen pribadi 23/06/2020

Dengan berdasarkan atas isu sirkulasi, orientasi, sirkulasi angin dan matahari serta kebisingan, maka mikro konsep dari tatanan lahan adalah bebas dan terarah. Zona yang ada didalam site terbagi menjadi 3 zona, yaitu: (a) Zona publik: Zona yang bersifat umum, sehingga semua orang dapat masuk ke area tersebut. Fasilitas yang terdapat pada area publik adalah bangunan penerima, fasilitas pendukung dan area parkir pengunjung; (b) Zona Transisi: Zona yang berada di tengah dan menghubungkan antara zona publik dan zona privat. Bersifat semi publik dan semi privat. Fasilitas yang terdapat pada area ini adalah fasilitas pertunjukan musik indoor, amphiteater outdoor dan fasilitas pelatihan music; dan (c) Zona Privat: Zona yang memiliki tingkat privasi tinggi, sehingga orang tertentu dan yang memiliki ijin saja yang dapat pergi ke area tersebut. Bangunan pada area privat adalah fasilitas pengelola, fasilitas service dan parkir pengelola.

\subsection{Bentuk Massa Bangunan}

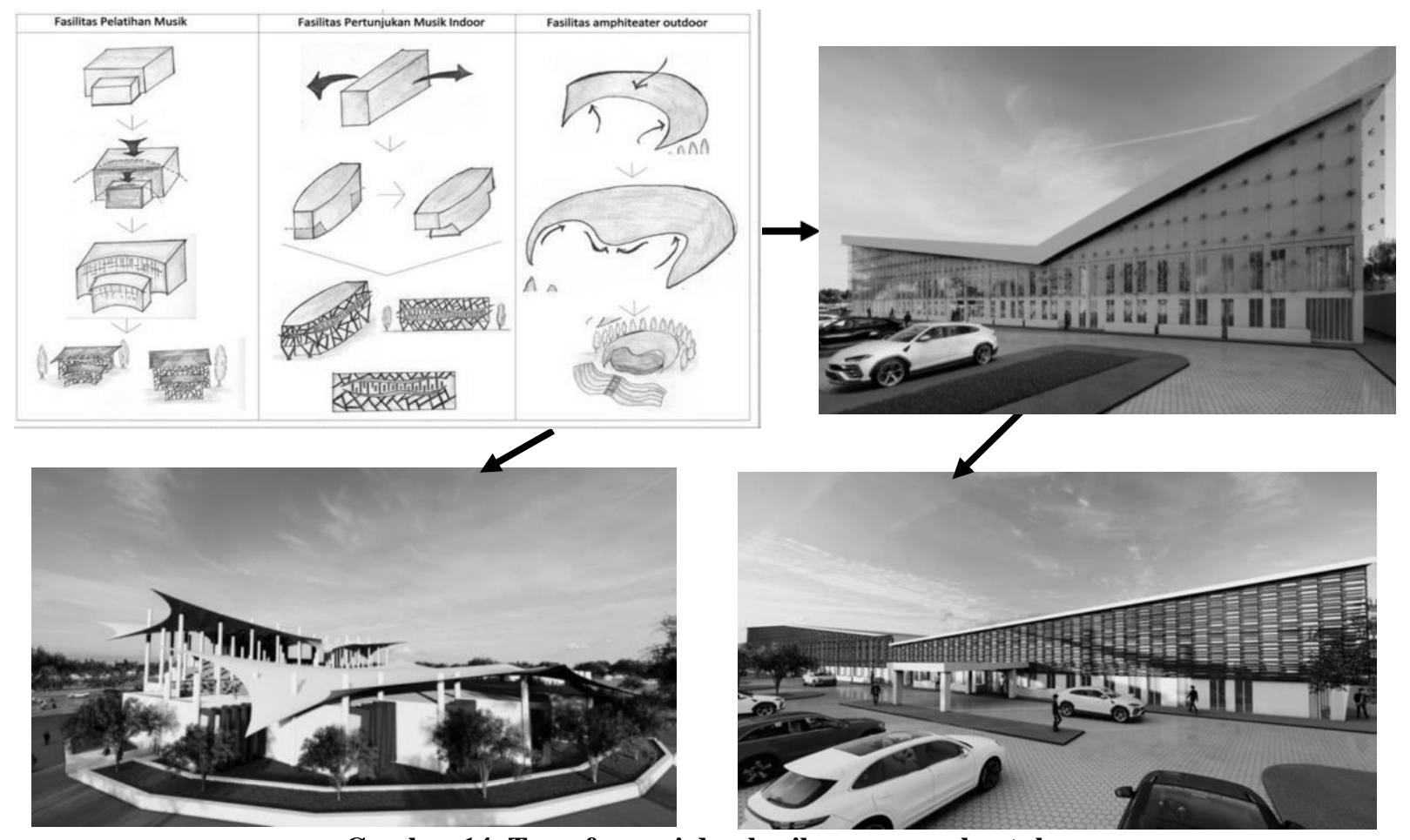

Gambar 14. Transformasi dan hasil rancangan bentuk

Sumber: dokumen pribadi 23/06/2020

Transformasi bentuk pada bangunan mengekspresikan secara tegas idealisme indie sendiri yang dinamis sekaligus dengan distorsi sehingga tidak terkesan kaku. Ide bentuknya juga diambil dari 
posisi orang yang sedang mengajak atau menghimpun, karena di dalam idealisme bermusik indie sendiri mempunyai banyak perbedaan dalam jenis karya musiknya, sehingga dengan ide bentuk tersebut dapat menggambarkan aspek persatuan dan solidaritas tetap jadi yang utama.

Dengan penggunaan material kaca, secondary skin panel-panel kayu, serta penggunaan atap membrane membuat keseluruhan hasil rancangan bentuknya memiliki kesan yang modern dan authentic. Dalam kaitannya dengan tema perilaku, bentuk dan material eksterior yang digunakan tersebut mempresentasikan gaya dan perilaku para penggiat musik umum secara umum,

\subsection{Ruang (Interior Bangunan)}
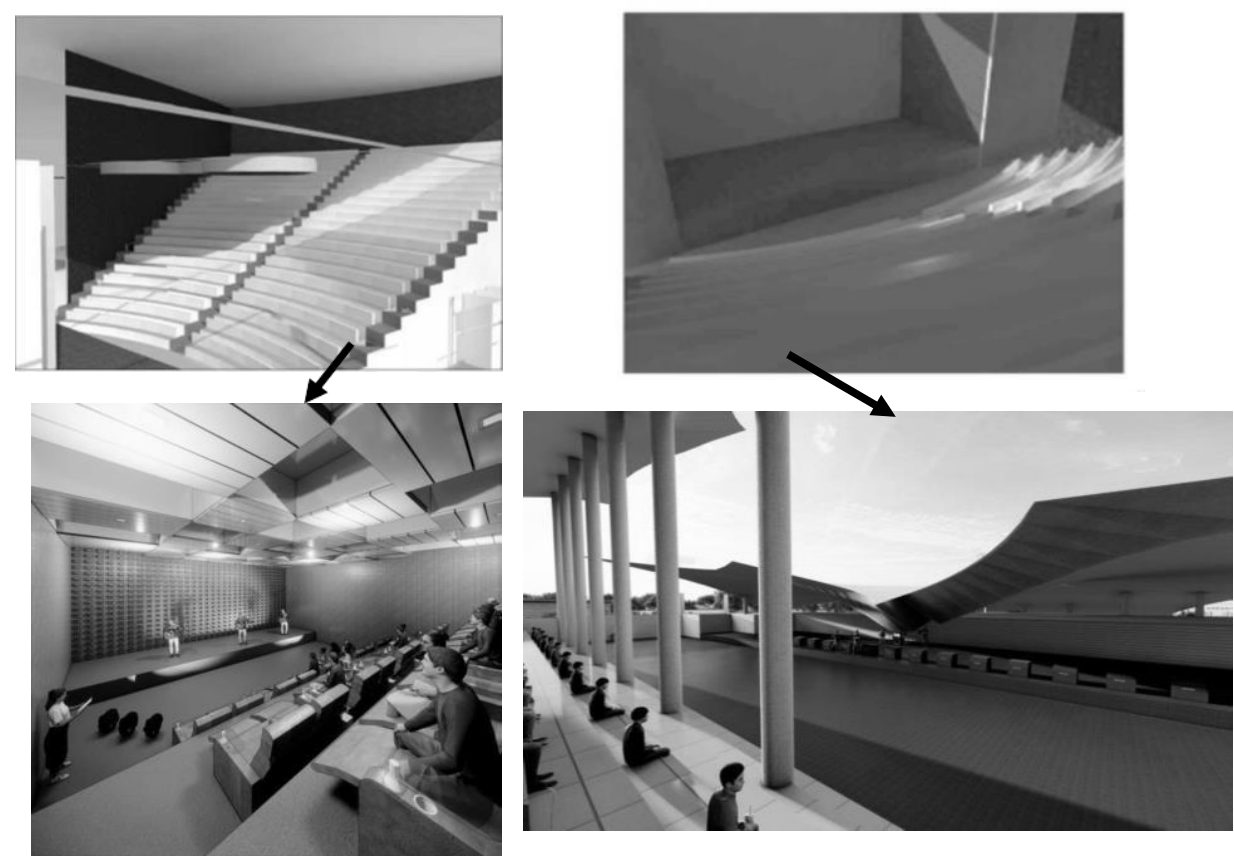

Gambar 15. Transformasi dan hasil rancangan ruang Sumber: dokumen pribadi 23/06/2020

Konsep mikro ruang yang digunakan adalah efektif, yang diharapkan dengan konsep tersebut maka ruang-ruangnya dapat difungsikan dan diguanakan secara tepat dan tanggap sesuai dengan kebutuhan dan aktivitas penggunanya. Sebagaimana aktivitas bermusik indie yang mempunyai banyak jenis kegiatan yang kompleks, yang mana membutukan ruang-ruang yang dapat mengakomodir berbagai aktivitas tersebut

Kesan harmoni juga digunakan untuk menggambarkan semngat musik indie sendiri, yaitu "indie saling berbagai dalam harmoni". Kesan harmoni tersebut diterapkan pada tatanan ruang yang lebih menghimpun dan menyatukan para penggiat musik indie didalamnya. Serta pada penggunaan material yang lebih selaras.

Penggunaan material akustik seperti lapisan fabric pada ruangan yang berfungsi sebagai ruang pertunjukan serta pencahayaan dan penghawaan alami ataupun buatan untuk menyesuaikan aktivitas bermusik, sehingga para pengguna dapat menggunakannya sesuai kebutuhan.

\section{Kesimpulan}

Pusat Kreasi dan Eksplorasi Musik Indie dengan menerapkan tema Arsitektur berwawasan Perilaku dengan tujuan utama sebagai wadah untuk mengkreasikan dan mengembangkan bakat bermusik para penggiat musik indie. Penerapan tema terhadap keseluruhan desainnya adalah dengan menyesuaikan desain bentuk, ruang dan tatanan lahannya mengikuti aktivitas perilaku para penggiat musik indie yang bebas, dinamis dan bersatu. Sehingga terjadi keterkaitan antara desain arsitektur dengan perilaku para musisi indie didalamnya. Dengan makro konsep Sebagai wadah untuk mengeksplorasi atau mengembangkan dan mengkreasikan musik indie yang mengacu pada aktivitas 
dan perilaku pengguna didalamnya. Dengan mengeksplorasi dan mengkreasikan musik indie maka diharapkan dapat mengembangkan dan menemukan hal-hal baru yang lebih kreatif dalam proses dan menghasilkan musiknya. Serta tetap mempertahankan idealisme bermusiknya yang independent. Konsep mikro bentuk yang rekreatif diterapkan dengan mengambil bentuk not bar lagu serta bentuk huruf "V" yang memperlihatkan idealisme bermusik indie dan dengan penggunaan bentuk yang sesuai dengan fungsi dan aktivitas yang ada didalamnya. Mikro konsep ruang yang efektif dengan penggunaan warna serta tekstur pada ruang yang juga disesuaikan dengan fungsi ruangannya, sehingga dapat memberi kesan yang berbeda-beda pada setiap fungsinya. Elemen akustik, penghawaan serta pencahayaan pada ruang-ruang yang digunakan untuk bermain musik secara langsung, harus diperhatikan sedemikian rupa sehingga dapat mempengaruhi kualitas musik yang dihasilkan. Konsep mikro tatanan lahan yang bebas dan terarah untuk memudahkan serta memperjelas sirkulasi dalam tatanan lahannya. Bebas dalam artian pengguna dapat dengan mudah mengakses seluruh fasilitas publik tetapi juga terarahkan dengan pola sirkulasi yang ditentukan. Sehingga para pengguna diharapkan tidak merasa kebingungan atau kesulitan dalam melakukan aktivitasnya didalam setiap fasilitas yang ada didalam site tersebut.

\section{Referensi}

Anggoro, Cahyo Dwi. (2010). Indie Community Music Center di Yogyakarta. [Diakses dari: http://ejournal.uajy,ac.id/2343/].

Heimsath, Clovis. (1977). Behavioral Architecture: Toward an Accountable Design Process. New York: McGraw-Hill Book Company.

Naldo (2012). Tesis, "Musik Indie Sebagai Perlawanan Terhadap Industri Musik Mainstream Indonesia". Jakarta FISIP UI Program Pasca Sarjana Jurusan Ilmu Komunikasi.

Tandal, Anthonius N., Egam, I Pingkan P. (2011). Arsitektur Berwawasan Perilaku (Behaviorisme). Media Matrasin Vol.8 No.1 Mei 2011. 
